\title{
Entrepreneurial Education and Entrepreneurial Culture among University of Cape Coast Students in Ghana
}

\author{
By Nina Afriyie* \\ Rosemond Boohene ${ }^{* *}$
}

\begin{abstract}
Currently the Ghanaian economy's capacity to absorb new recruits into the formal sector has fallen. Therefore, for young people to escape the incidence of not getting employed after school, active intervention is necessary. There is an urgent need for young people to be trained and educated in the field of entrepreneurship especially university students. This study examined the link between entrepreneurship education and entrepreneurial culture among university students in Ghana. A sample of 203 students was randomly selected from the three schools in University of Cape Coast Ghana. Correlation coefficient was the parametric statistical tools used to test the association in the study. Entrepreneurial culture was measured using entrepreneurial mindset, business startup motives and entrepreneurial orientation. Four dimension were used under entrepreneurial orientation; proactiveness, perseverance, innovativeness and risk taking propensity. A significant relationship was observed between entrepreneurship education and entrepreneurial culture. This study therefore argues that entrepreneurship education will equip the students with the skills with which to be self-reliant. Results again holds the implication for among others, that if entrepreneurship education is made core and studied by all students irrespective of the areas of specialization, will help inculcate the culture of entrepreneurship in University of Cape Coast students leading to they being job creators rather than job seekers, and in the long term effect, graduate unemployment will be reduced.
\end{abstract}

\section{Introduction}

Entrepreneurship is a remarkable force that has a huge impact on facilitating growth and societal progress of a nation. It involves innovation, employment generation and social empowerment. Education in the area of entrepreneurship may help people to develop skills and knowledge, which

\footnotetext{
*Professor, University of Cape Coast, Ghana.

${ }^{* *}$ Professor, University of Cape Coast, Ghana.
} 
could benefit them for starting, organizing and managing their own enterprises (Reynolds et al, 2001). An enterprising culture today is what is needed to ensure that entrepreneurship thrive. Blokker and Dallago (2008) establish that if entrepreneurial and enterprising behavior among young people especially university students is to emerge, more focus must be put on entrepreneurship education and methodologies that encourage 'learning by doing' and 'just in time learning'.

Mugione, chief entrepreneurship advisor, in 2011 at United Nations conference on Trade and Development accentuated that entrepreneurship education at the university level should not be limited to those at the business school alone, since student on other programs could also become entrepreneurial in their field of study. Thus entrepreneurship education is not only a means to foster Youth Entrepreneurship but at the same time to equip young people with entrepreneurial attitude and skills (Schoof, 2006).

Liikanen (2004), also adds that enterprising culture provides benefits to society even beyond their application to business activity. In fact, personal qualities that are relevant to entrepreneurship such as creativity, innovation and spirit of initiative can be useful to everyone in their working activities and in their daily lives. Entrepreneurial culture can be attained through various factors. One way of promoting entrepreneurial culture is through entrepreneurship education. Ngosiane (2010), in his work promoting an entrepreneurial culture in Kenya revealed that entrepreneurship education can help promote entrepreneurial culture through the formation of clubs at the various universities.

This presupposes that entrepreneurship education improves entrepreneurial culture. This again reinforces Gibbs and Lyapunov (1996) proposition which suggest that an entrepreneurial culture needs to be nurtured to support SMEs in areas such as values, beliefs, attitudes and behavioural norms. Entrepreneurship education and entrepreneurial culture are the instruments that make an individual to act in a particular manner. In the words of Deci and Ryan (2000), the more able you are, the more willing you are. Ability can be transpired through learning.

Numerous researches have focused on the teaching and learning of entrepreneurship education to accelerating economic growth and development. In the study carried out by Arogundade, (2011), discovered the importance of entrepreneurship education towards improving sustainable economic development in Nigeria. Again a study carried out by Raposo and Paco (2000) revealed that entrepreneurship education is not just about teaching someone to run a business. It is also about encouraging creative thinking and promoting a strong sense of self-worth and empowerment. This is what is desirable for economic growth and development. However there is very little literature that has attempted to establish the association between entrepreneurship education and entrepreneurial culture particularly in Ghana. Development of entrepreneurial culture in a country among the citizenry especially the youth, leads to a situation where the majority of population takes up self-employment as a career and firmly believes it is better than wage employment (Gibb, 2003). 
Hence the purpose of this study was to establish the relationship between entrepreneurship education and entrepreneurial culture among university of Cape Coast students in Ghana. The paper will contribute to the ongoing discussion making entrepreneurship education a core course at all levels of education especially at the higher levels.

\section{Literature Review}

\section{Entrepreneurship Education in Universities}

Entrepreneurship education is decisive for developing entrepreneurial skills, attitudes and behaviors that form the basis for the economic growth of a country. Entrepreneurship education at universities can have a positive influence in attitudes towards entrepreneurship, and in turn promote entrepreneurship as a useful and respectable career prospect for graduates (Galloway and Brown).Universities, can be seen as engines of scientific and technological invention and play an important role in transforming the invention and technological development into innovation (Volkmann2009). Universities play a key role in harnessing the talents of students, graduates and researchers.

A university can be conceptualized as a societal innovation system, and entrepreneurship education, when entrenched in such a system, could be regarded not only as a task of producing entrepreneurially oriented competent individuals, but also reproducing the social mechanisms that underpin and facilitate the birth and growth of businesses (Petridou 2009). In addition, universities play a key role as entrepreneurial nucleus, linking researchers, students, entrepreneurs, business enterprises and other stakeholders. In other words, the objectives of entrepreneurship education are aimed in changing students' state of behaviors and even intention that makes them to understand entrepreneurship, to become entrepreneurial and to become an entrepreneur that finally resulted in the formation of new businesses as well as new job opportunities (Fayolle and Gailly 2005).

They can also play a role in developing entrepreneurial traits in students (Jesselyn and Mitchell, 2006). With the recent increase of university graduates and self-employment and business ownership being perceived as growing employment opportunities, it has been recognized and acknowledged that higher education needs to be equipping its graduates better for the diverse range of skills required to manage this type of work (Carey and Naudin, 2006).

\section{Entrepreneurship Education}

Entrepreneurship education is a concept of Entrepreneurship and Education. Bird (1989) defines entrepreneurship as 'the creation of value through creation of organization that is, the process of starting and or growing a new profit making business. Nwangwu (2007) opined that entrepreneurship is a process of bringing together the factors of production, which include land, 
labor and capital so as to provide a product or service for public consumption. Wennekers, Uhlaner and Thurik (2002) distinguishes three types of entrepreneurship that includes; (a) static entrepreneurship defined by selfemployed and has come as a result of 'shopkeeper effect or refugee effect', (b) the dynamic entrepreneurship defined by new venture creation (nascent entrepreneurs) which has a 'Schumpterian effect' and (c) Corporate entrepreneurship defined as entrepreneurial behavior in large organization.

Although each of the above definitions views entrepreneurship from slightly different perspectives, they contain four common notions or elements that are crucial to this study. Entrepreneurial is considered as that kind of behavior that includes; opportunity recognition or perception, organizing and reorganizing of social and economic mechanisms to turn resources and situations to practical account, the acceptance of risk or failure and initiative taking. Education which is a learning process is consider as some kind of behavior that the individual exhibit after learning has taking place (Classical and Operant learning). Hence entrepreneurial education can imbibe in the university students of Cape Coast to exhibit entrepreneurial behavior, hence entrepreneurial culture.

UNESCO classified education as comprising organized and sustained communication designed to bring about learning. Education is the acquisition and transmission of excellences of body, mind and character. The definition does not focus on infrastructures of education as an activity but on what qualities should come out of the person through the process of education. Education therefore leads to the development of knowledge, values and habits. Entrepreneurial education is defined as the whole set of education and training activities within the educational system or not that try to develop in the participants the intention to perform entrepreneurial behaviors or some of the element that affect that intention, such as entrepreneurial knowledge, desirability of the entrepreneurial activity, or its feasibility.

Entrepreneurship Education is described as "the teaching of knowledge and skills that enables the students to plan, start and run their own business." Therefore the role of entrepreneurship education is mainly to build an entrepreneurial culture among young people that, in turn, would improve their career choices towards entrepreneurship (Deakins \& Glancey 2005). The policy implications of Global Entrepreneurship Monitor (GEM, 2001) indicated that people with limited entrepreneurship education are less likely to participate in entrepreneurial initiatives. Therefore getting an adequate education may foster entrepreneurial intention of a person and this will spill over to a startup motive. The primary purpose of entrepreneurial education in this study is to help in the development of entrepreneurial culture among the university of Cape Coast students in Ghana. Entrepreneurship education is used as an independent Variable in the study.

\section{Entrepreneurial Culture (EC) and Entrepreneurship Education (EE)}

As far as culture is concerned, Kroeber and Parson's (2003) earlier crossdisciplinary definition of culture included "patterns of values, ideas, and other 
symbolic-meaningful systems as factors in the shaping of human behavior". Hofstede (1984) refers to culture as "the collective programming of the mind which distinguishes the members of one human group from another, and includes systems of values". The concept of "entrepreneurial culture" may also vary, but generally it may refer to the norms, beliefs and shared values of a particular region/community. According to Timmons (2008) it is "the ability to create and build something from practically nothing. It is initiating, doing, achieving and building an enterprise or organization, rather than just watching, analyzing or describing one. It is the knack for sensing an opportunity where others see chaos, contradiction and confusion." Development of entrepreneurial culture is a long term process where various stakeholders such as government, the private sector, communities, educators, and parents have to entrench and develop positive attitudes towards entrepreneurship (Gouws, 2002).

Education is an important contributor to the development of an entrepreneurial culture. Gouws (2002), stated succinctly that the key success in establishing a culture of entrepreneurship is South Africa is education. Driver and Wood (2001), in the South African GEM stated that the education and training was the most important factor that prohibited the growth of entrepreneurship culture. Positive attitudes towards entrepreneurship would, however, only be the beginning of the empowerment process as the long term ideal would be that an increased number of individuals would translate their positive attitudes into entrepreneurial activity by start and running their own business. This study used entrepreneurial culture as a dependent variable, and it was measured using three indicators; entrepreneurial mindset, entrepreneurial startup motives and entrepreneurial orientation.

This study considers entrepreneurial culture as the dependent concept. Entrepreneurial culture is operationalised as a dynamic process that involves three critical stages namely entrepreneurial mindset, business start-up motives and entrepreneurial orientation. Concerning the independent variable, literature reviewed disclose that entrepreneurship education equip people with the needed skills for them to become entrepreneurial. Mode of teaching entrepreneurship education is conceived as an intervening variable.

From the conceptual from work, the following hypotheses were drawn:

$\mathrm{H}_{01}$ : there is no statistical significant difference between entrepreneurial education and entrepreneurial mindset.

$\mathrm{H}_{02}$ : there is no statistical significant difference between entrepreneurial education and startup motives

$\mathrm{H}_{03}$ : there is no statistical significant difference between entrepreneurial education and entrepreneurial orientation.

$\mathrm{H}_{04}$ : there is no statistical significant difference between entrepreneurial education and entrepreneurial culture.

$\mathrm{H}_{05}$ : there is no statistical significant relationship between modes of teaching entrepreneurship education and entrepreneurial culture. 
Vol. 1, No. $4 \quad$ Afriyie et al.: Entrepreneurial Education and Entrepreneurial Culture...

\section{Research Design}

A descriptive research design was used for the study.

\section{Population and Sample}

The target population was level 300 students of the home economics and agricultural science department as well as 2012/2013 graduates from school of business. These three groups were chosen because they offer entrepreneurship or enterprise education as a core course, in University of Cape Coast and as a matter of fact they can best tell whether entrepreneurship education had or is having a positive impact in their lives. A total population size of 547 was obtained. Out of this 203 was statistically obtained using a precision of $5 \%$ and a confidence level of 95\% (Mugenda \& Mugenda, 2003).

Table 1. Distribution of the Sample

\begin{tabular}{cccc}
\hline Strata & Population Size & Proportion & Sample Size \\
\hline Faculty of Education: & & & 33 \\
Home Economics: & 89 & $16.3 \%$ & \\
School of Agriculture & & & 22 \\
Science & 58 & $10.6 \%$ & 148 \\
School of Business & 400 & $73.1 \%$ & $\mathbf{2 0 3}$ \\
Total & $\mathbf{5 4 7}$ & $\mathbf{1 0 0}$ &
\end{tabular}

Probability sampling method was used for the study. Random sampling technique was used to obtain the sample size for home economics and agricultural science students. For the graduated students, since they are no longer on campus snowball sampling was used to obtain the sample size.

\section{Research Instrument}

A self-designed 30-item questionnaire was used to collect primary data relating to the variables of the study from the sampled 203 University of Cape Coast students in Ghana. Before use, the questionnaire was distributed to experts for validity. To test for reliability, the study used the internal consistency technique by employing Cronbach Coefficient Alpha test for testing the research tool. According to Mugenda and Mugenda (2003), the coefficient is high when its absolute value is greater than or equal 0.7 otherwise it is low. A high coefficient implies high correlation between variables indicating a high consistency among the variables. The study made used of quantitative approach in analysing the data.

\section{Data Analysis Method}

This examined the correlation between entrepreneurship education and development of entrepreneurial culture among university of Cape Coast students in Ghana. Five null hypotheses were formulated based on the 
reviewed literature. Data obtained from the study were analysed using descriptive statistics and inferential statistics (Pearson correlation and Chisquare test of independency).

Table 2 presents the results of descriptive characteristics of the respondents. The results show that, out of the total sample population of 203 the male samples constituted $56.7 \%$ while females sample constituted the remaining $43.3 \%$. A glance through Table 2 show that, $66.5 \%$ of respondents were within the age range of $22-25,30.5 \%$ were within the range of $26-30$ and the $3.0 \%$ fell within the age range of $31-35$.

In this study, $54.2 \%$ of the sample population pursued Bachelor of Commerce, $18.9 \%$ pursued bachelor of management studies, $16.3 \%$ are pursing home economics and $10.6 \%$ are pursing agricultural science. The Table 2 shows that as much as $98.5 \%$ of the sampled population had ever thought of a business idea while $1.5 \%$ had never thought of such idea. The study also revealed that as many as $56.2 \%$ of the respondents indicated that they will look for salaried jobs after school or National service, $35.5 \%$ hope to start their own business and the remaining $8.4 \%$ will go into franchising and grow their own business. About $36 \%$ of respondents indicated that the ideal level for the teaching and learning of entrepreneurship course as a core should be level 300, $25.6 \%$ suggested level 100, 23.6\% level 200 and $15.8 \%$ level 400 .

\section{Test of Hypothesis}

All the five hypotheses were tested using two different methods. First, Pearson's correlation test was employed to examine the level of association between an indicator of entrepreneurial culture and entrepreneurship education. Table 3, show the results of the correlation analysis between entrepreneurship education and entrepreneurial culture, while the Chi square test of difference is presented in Table 4. For clarity, each hypothesis is presented separately.

Hypothesis One: The first hypothesis predicted that development of entrepreneurial mindset among university of Cape Coast students does not depend on the teaching and learning of entrepreneurship education. The null hypothesis of no significant difference between entrepreneurship education and entrepreneurial mindset is rejected at 0.05 level of significant. Results presented in Table 3and 4, shows a positive relationship between entrepreneurship education and entrepreneurial mindset at $95 \%$ and $99 \%$ confidence interval $(r=0.13, p<0.05),\left(X^{2}=41.757\right.$, df $\left.=3, p=0.00\right)$. Results holds the implication that when entrepreneurship education is made core for all university of Cape Coast students, entrepreneurial culture in the area of entrepreneurial mindset, aspirations and intentions will be exhibited. 
Vol. 1, No. $4 \quad$ Afriyie et al.: Entrepreneurial Education and Entrepreneurial Culture...

Table 2. Descriptive Statistics of the Profile of Respondents

\begin{tabular}{|c|c|c|c|c|c|c|c|}
\hline \multirow{3}{*}{$\begin{array}{c}\text { BIODATA } \\
\text { Gender }\end{array}$} & CATEGORIES & FREQ & \multicolumn{2}{|c|}{ PERCENT } & $\begin{array}{c}\text { CUM } \\
\text { PERCENT }\end{array}$ & $\begin{array}{l}\text { STD } \\
\text { DEV }\end{array}$ & MEAN \\
\hline & Male & 115 & \multicolumn{2}{|c|}{56.7} & 56.7 & & \\
\hline & Female & 88 & \multicolumn{2}{|c|}{43.3} & 100.0 & 0.4968 & 1.4335 \\
\hline \multirow[t]{3}{*}{ Age } & $22-25$ & 135 & \multicolumn{2}{|c|}{66.5} & 66.5 & & \\
\hline & $26-30$ & 62 & \multicolumn{2}{|c|}{30.5} & 97 & & \\
\hline & $31-35$ & 6 & \multicolumn{2}{|c|}{3.0} & 100.0 & & \\
\hline \multirow{4}{*}{$\begin{array}{l}\text { Programme } \\
\text { Pursued by } \\
\text { Students }\end{array}$} & \multicolumn{2}{|c|}{ B.COM } & 110 & 54.2 & 40.9 & & \\
\hline & \multirow{2}{*}{\multicolumn{2}{|c|}{$\begin{array}{c}\text { BMS } \\
\text { Home Fconomics }\end{array}$}} & 38 & 18.7 & 9.4 & & \\
\hline & & & 33 & 16.3 & 29.6 & & \\
\hline & \multicolumn{2}{|c|}{ Agricultural science } & 22 & 10.8 & 100.0 & 1.1979 & 2.2906 \\
\hline \multirow{6}{*}{$\begin{array}{l}\text { Ideal level for } \\
\text { teaching and } \\
\text { learning of } \\
\text { Entrepreneurship }\end{array}$} & \multirow{2}{*}{\multicolumn{2}{|c|}{100}} & & & & & \\
\hline & & & 50 & 24.6 & 24.6 & & \\
\hline & \multicolumn{2}{|c|}{200} & 48 & 23.6 & 48.0 & & \\
\hline & \multicolumn{2}{|c|}{300} & 73 & 36.0 & 85.0 & & \\
\hline & \multicolumn{2}{|c|}{400} & 32 & 15.8 & 100.0 & & \\
\hline & & & & & & 1.0286 & 2.4286 \\
\hline \multirow{3}{*}{$\begin{array}{l}\text { Conception of } \\
\text { business idea }\end{array}$} & \multicolumn{2}{|c|}{ Yes } & 200 & 98.5 & 98.5 & & \\
\hline & \multirow{2}{*}{\multicolumn{2}{|c|}{ No }} & 3 & 1.5 & 100 & & \\
\hline & & & & & & 0.12096 & 1.0148 \\
\hline \multirow{6}{*}{$\begin{array}{l}\text { Entrepreneurial } \\
\text { Mindset }\end{array}$} & \multicolumn{2}{|c|}{ Strongly Agree } & 92 & 45.3 & 45.3 & & \\
\hline & \multicolumn{2}{|c|}{ Agree } & 91 & 44.8 & 90.1 & & \\
\hline & Unce & & 15 & 7.4 & 97.5 & & \\
\hline & Disa & & 3 & 1.5 & 99.0 & & \\
\hline & Strongly & agree & 2 & 1.0 & 100.0 & & \\
\hline & & & & & & 1.7291 & 1.000 \\
\hline Business & Strongly & gree & 51 & 25.1 & 25.1 & & \\
\hline & $\mathrm{Ag} 1$ & & 94 & 46.3 & 71.4 & & \\
\hline & Unce & & 47 & 23.2 & 94.6 & & \\
\hline & Disa & & 11 & 5.4 & 100.0 & & \\
\hline & & & & & & 0.8337 & 2.0887 \\
\hline $\begin{array}{c}\text { Life after } \\
\text { School/Service }\end{array}$ & $\begin{array}{l}\text { Look for } \\
\text { jo }\end{array}$ & laried & 114 & 56.2 & 56.2 & & \\
\hline & $\begin{array}{r}\text { Identify a } \\
\text { Opportu }\end{array}$ & $\begin{array}{l}\text { siness } \\
\text { and }\end{array}$ & 72 & 35.5 & 91.7 & & \\
\hline & $\begin{array}{r}\text { star } \\
\text { Partner } \\
\text { existing B } \\
\text { grow th }\end{array}$ & $\begin{array}{l}\mathrm{h} \text { an } \\
\text { ness to } \\
\text { own }\end{array}$ & 17 & 8.4 & 100 & & \\
\hline & & & & & & 0.6474 & 1.5222 \\
\hline
\end{tabular}


Table 3. Correlation Coefficients between Entrepreneurship Education and Indicators of Entrepreneurial Culture

\begin{tabular}{ccc} 
Indicators of Entrepreneurial & & Entrepreneurship Education \\
Entrepreneurial Mindset and & & \\
Intentions & $\mathrm{r}$ & 0.13 \\
& $\mathrm{p}$ & 0.05 \\
Startup Motives & $\mathrm{r}$ & 0.30 \\
& $\mathrm{p}$ & 0.00 \\
Entrepreneurial Orientation & $\mathrm{r}$ & 0.30 \\
& $\mathrm{p}$ & 0.004 \\
Entrepreneurship Culture & $\mathrm{r}$ & 0.30 \\
& $\mathrm{p}$ & 0.05 \\
Mode of Teaching & & 0.14 \\
Entrepreneurship Education & $\mathrm{r}$ & 0.05 \\
\hline correlation is significant at the level $0.05\left(2-\right.$ tailed), ${ }^{* * *}$ correlation is significant at the level
\end{tabular}

Table 4. Chi-Square Test Statistics for all the Variable

\begin{tabular}{|c|c|c|}
\hline & $\begin{array}{c}\text { Entrepreneurial Intentions, Aspirations, and } \\
\text { Mindset }\end{array}$ & $\begin{array}{l}\text { Entrepreneurship } \\
\text { Education }\end{array}$ \\
\hline Chi-Square & $41.757^{\mathrm{a}}$ & $112.964^{\mathrm{a}}$ \\
\hline $\mathrm{df}$ & 3 & 3 \\
\hline \multirow[t]{2}{*}{ Asymp. Sig. } & 0.000 & 0.000 \\
\hline & Start Up Motives & $\begin{array}{l}\text { Entrepreneurship } \\
\quad \text { Education }\end{array}$ \\
\hline Chi-Square & 67.333 & 112.964 \\
\hline $\mathrm{df}$ & 4 & 3 \\
\hline \multirow[t]{2}{*}{ Asymp. Sig. } & 0.000 & 0.000 \\
\hline & Entrepreneurship Education & $\begin{array}{l}\text { Entrepreneurial } \\
\text { Orientation }\end{array}$ \\
\hline Chi-Square & $112.964^{\mathrm{a}}$ & $148.856^{\mathrm{a}}$ \\
\hline $\mathrm{df}$ & 3 & 3 \\
\hline \multirow[t]{2}{*}{ Asymp. Sig. } & .000 & .000 \\
\hline & Entrepreneurship Education & Entrepreneurial Culture \\
\hline Chi-Square & $112.964^{\mathrm{a}}$ & $126.441^{\mathrm{a}}$ \\
\hline $\mathrm{df}$ & 3 & 3 \\
\hline \multirow[t]{2}{*}{ Asymp. Sig. } & .000 & .000 \\
\hline & Entrepreneurial Education & Mode of Teaching \\
\hline Chi-Square & $112.964^{\mathrm{a}}$ & $95.378^{\mathrm{a}}$ \\
\hline $\mathrm{df}$ & 3 & 3 \\
\hline Asymp. Sig. & .000 & .000 \\
\hline
\end{tabular}


Hypothesis two: stated that, $\mathrm{H}_{02}$ : Statistically, there is no significant difference between entrepreneurship education and startup motives. That is, University of Cape Coast students' ability to start up their own business rather than look for a salaried work has nothing to do with entrepreneurship education. Tables3and 4, shows a significant positive relationship between entrepreneurship education and startup motives was recorded at $99 \%$ confidence interval $(\mathrm{r}=0.30, \mathrm{p}<0.01),\left(\mathrm{X}^{2}=67.333, \mathrm{df}=4, \mathrm{p}=0.00\right)$. Hence the null hypothesis has been rejected. This implies therefore that when entrepreneurship education is made a core course for the UCC students, will develop startup motives among the students.

The third hypothesis which predicted that statistically, there is no significant difference between entrepreneurship education and entrepreneurial orientation was rejected at 0.05 level of significance. The results are presented in Tables3and 4, see Appendix. Result from the correlation shows a positive significant relationship between entrepreneurship education and entrepreneurial orientation at $95 \%$ confidence interval $(r=0.30, p<0.05),\left(X^{2}=148.856, d f=\right.$ $3, \mathrm{p}=0.00)$. The null hypothesis of no significant difference between entrepreneurship education and entrepreneurial orientation is rejected at 0.05 level of significant. Indication is that, EE can promote EC in the area of entrepreneurial orientation.

Hypothesis Four $\left(\boldsymbol{H}_{04}\right)$ this hypothesis predicted that, statistically, there is no significant difference between entrepreneurial education and entrepreneurial culture. The results are presented on tables3and 4, see Appendix. A positive significant relationship at 0.05 for the $p$ value, $r=0.30$ was indicated. Results from chi-square statistics recorded $\left(X^{2}=126.441, d f=3, p=0.00\right)$. The null hypothesis of no significant difference between entrepreneurship education and entrepreneurial culture is rejected at 0.05 level of significant. This implies that whenever EE is made a core course for UCC students, EC will be promoted along the lines used as indicators.

The fifth hypothesis which predicted that statistically, there is no significant relationship between modes of teaching entrepreneurship education and entrepreneurial culture was rejected at 0.05 level of significant. The study tried to establish whether the pedagogy of teaching EE has an influence on Entrepreneurial Culture. Results presented on Tables 3 and 4shows that there is a connection between the way EE is taught and development of EC at a significance level of $(\mathrm{p}<0.05, \mathrm{r}=0.20)$. Chi square statistics $\operatorname{recorded}\left(\mathrm{X}^{2}=\right.$ 95.378, $\mathrm{df}=3, \mathrm{p}=0.00$ ). It implies that development of EC is dependent on the pedagogy of teaching EE, hence the study rejected the null hypothesis.

\section{Discussion}

The study examined the link between entrepreneurship education and entrepreneurial culture among university of cape coast students in Ghana. The results revealed the following.

Conception of Business Idea: Almost all respondents in the sample had taught of a business idea and that idea only became a mirage due to lack of support; technical, financial, emotionally and psychologically. The findings 
reinforces the fact that support in any of the forms mentioned above can and will promote business start ups Ngosiane (2010).

Type of Employment Students wish to have: More than $36 \%$ of the respondents hopes to get a salaried employment after school. This presupposes that entrepreneurial culture is very low among university students in Ghana and specifically university of Cape Coast students. This again reinforces (Gibb, 2003)that in a country where citizens especially the youth are prepared take up wage employment than being self-employed indicates that the country has low entrepreneurial culture.

Entrepreneurial Intentions, Aspirations and Mindset: More than $80 \%$ of the respondents agreed students constantly thinking and talking about entrepreneurship are an indication of students having a culture of entrepreneurial culture. Results from the correlation carried out indicates that entrepreneurship education can and will promote entrepreneurial culture. This outcome is in agreement with O'Neil and Mahadea (2005), research work which indicate that entrepreneurship education is perceived as a significant contributor to the development of entrepreneurial mindset, skills and attitudes.

Start-up Motives: More than $75 \%$ of the respondents agreed that students having the confidence to going ahead and starting their own business are an indication of students having developed entrepreneurial culture. Inferential statistics carried out directed that, there is a link between entrepreneurship education and entrepreneurial culture. These suggests that student's intentions of starting their own business is significantly related to entrepreneurial education. This outcome reinforces the work of Bandura (1986), that entrepreneurship education can serve as a preparatory function in relation to new venture initiation or start-up, whereby the transfer of knowledge and the acquisition and development of relevant skills would be expected to increase the self-efficacy and effectiveness of the potential entrepreneur.

Entrepreneurial Orientation: Almost all respondents in the sample regard entrepreneurial orientation as an indicator of entrepreneurial culture with respect to students being innovative, proactive, having the spirit of perseverance and being able to take moderate risk. This outcome is in agreement with the research work of (Korir, 2006)

Entrepreneurship education and entrepreneurship culture: More than $60 \%$ of the respondent agreed to the assertion that entrepreneurship education can promote entrepreneurial culture along the lines of the indicators used in the study. The findings is congruent to the research work by O'Neil and Mahadea, (2005). Chi square results also confirmed all these relationship to be significant.

Mode of Teaching: About $80 \%$ of the respondent agreed that the pedagogy for teaching and learning of entrepreneurship education should be practically based if entrepreneurial culture is to be promoted. Results from correlation and chi square indicated a positive relationship between modes of teaching entrepreneurship education. Thus it can be concluded that there is definite 
pedagogical impact of entrepreneurship education on the university of Cape Coast students

\section{Conclusion}

Entrepreneurship is undoubtedly seen as an engine of growth in countries, including Ghana. The president of Ghana and various other stakeholders are making assiduous effort to promote entrepreneurship as a means of curbing the rate of unemployment in Ghana. Entrepreneurship education which has been seen in literature as one of the tools that can used to promote EC and entrepreneurial activity in a country, has not been adequately looked at in Ghana. Entrepreneurial culture of a country affects the attitude that individuals have towards entrepreneurship, the likelihood of choosing entrepreneurship as a career, the ambition to succeed, to start again after failure, and or the support provided to a family and relatives planning to set up a business. The study therefore concludes based on its findings that making EE a compulsory course for all university student in Ghana and specifically UCC students will help develop EC. This will in effect help increase the level of entrepreneurial activity in Ghana. Based on the findings of the study the following recommendations are made:

To help promote entrepreneurship in the country, then entrepreneurship must be made a compulsory course for all university students and specifically for UCC students not only for business, home economics and agriculture students. Similarly, the level ideal for teaching and learning of EE, the study revealed is level 300, and a practical assessment be done in level 400. Again, if the teaching and learning of entrepreneurship is to succeed and achieve it essence, then the needed resources, structures, and facilities must be put in place to make it more of a practical oriented course than theory based.

\section{References}

Bandura, A. (2001). Social Cognitive Theory of Mass Communication, Media Psychology, Available at http://www.masscom.com.accessed on $14^{\text {th }}$ August, 2011.

Ball, D. \& McCulloch, H. W. (1993). International business: introduction and essentials New York: Irwin

Bird, B. J. (1989). Entrepreneurial Behaviour. Glenview: Foresman\& co.

Deci, B. \& Ryan, B. (2000), Willingness to Enterprise. Available at http://www accessed on the $18^{\text {th }}$ of June, 2011.

Deakins, D. \&Glancey, K. (2005). Enterprise education: The role of Head Teachers. International Entrepreneurship and Management Journal. Vol1: 241-263.

Fayolle, A. G., Gailly, B., Hannon, O., Venkatachalam and Waqif, A. (2005). Using the Theory of Planned Behaviour to assess entrepreneurship teaching programmes, Centre for Research in Change, Innovation and Strategy: 1-18. Available at http://www.ijbssnet.com/journals/Vol._2_No._4\%3B_March_2011/ 24.pf 
Gibb, A.A. (2003). Organising for enterprise in China: what can be learned from the Chinese micro, small and medium enterprise development experience? Futures, 35 pp. 403 421. Pergamons.

Gouws, H. (2002). Positive attitude towards entrepreneurship. Available at http:// www.entrepreneurialculture.org accessed on $16^{\text {th }}$ December 2011.

Hofstede, G. (2003). East African Cultural dimensions Explained Geert HodfstedeWebsite: International- business centre.com accessed on $18^{\text {th }} \mathrm{July,}$ 2011

Korir, M. (2006) Role of Socio- Cultural Factors in Promoting EntrepreneurshipEldoretMunicipality. ( $\mathrm{PhD}$ Thesis). Kenyatta University, Nairobi, Kenya.

Mugenda, O. \&Mugenda, A.G. (2003) Research Methods: Quantitative \& Qualitative ApproachesActs Press Nairobi, Kenya ISBN 9966411070

Ngosiane, (2010), Role of entrepreneurship in the economy and society: promoting and entrepreneurial culture in Kenya

O'Neil, C. \&Mahadea, D. (2003) The Impact of Previous knowledge and experience on the entrepreneurial Attitudes of Grade 12 learners available at http://www. ajol.info accessed on the $19^{\text {th }}$ July, 2011.

Schoof, U. (2006). Stimulating Youth Entrepreneurship: Barriers and incentives to enterprise start-ups by young people, ILO, SEED Working Paper No. 76

Schumpeter, J. A. (1961) The Theory of Economic Development. New York: Oxford University Press.Timmons, J. A. \&Spinelli, S. (2003) New Venture Creation: Entrepreneurship for the $21^{\text {st }}$ century (International ed), Boston: McGraw-Hill. 
